\title{
THE CONCEPTION OF PERSON-ORIENTED EDUCATION FOR STUDENTS
}

The article describes the main regulations of the person-oriented conception for students in the Institutes of Higher Education. They are: organization of teaching and educational process according to the personal curriculum of a student, creating the timetable in accordance with the "disciplinary» principle, flexible educational schedule, providing students a possibility to determine the time and quantity of their own schedule, maintenance of the student's mobility and possibility to complete and to hand in their subject and test papers, realization of subject and total progress check and implementation of the monitoring system to control the progress in studies.

Keywords: person-oriented education, principles, forms of education, personal curriculum of a student, subject and total progress check.

\section{УДК 006.73}

К. А. Лозова, О. М. Алєксєєв, д.пед.н.

Сумський державний університет, м. Суми

\section{СЕРТИФІКАЦІЯ ПРОФЕСОРСЬКО-ВИКЛАДАЦЬКОГО СКЛАДУ ПРИ ЗМШШАНОМУ НАВЧАННІ}

У статті розглядаються питання сертифікаџії професорсько-викладаџького складу ВНЗ при впровадженні змішаної форми освіти. Проаналізовано та згруповано критерії компетентності викладача в системі освіти з широким використанням IКТ. Особливу увагу приділено експертній оцінщі представлених критеріїв та виявленню найбільш значущиих з них для інженерних спеціальностей. На основі дослідження доопрацьована система оцінювання та запропоновані нові критерії компетентності викладача зміманої форми освіти.

Ключові слова: професорсько-викладацький склад (ПВС), змішана форма освіти, сертифікація викладачів, професійні компетенції, критерії компетентності викладачів, експертна оцінка.

Постановка проблеми. Процеси глобалізації освітнього середовища і науковотехнічний прогрес висувають нові вимоги до рівня компетентності викладачів, як основного чинника забезпечення конкурентоспроможності університетів. Одним 3 найбільш популярних і актуальних способів оцінювання рівня знань, вмінь i навичок професорсько-викладацького складу є сертифікація. На жаль, навіть і сьогодні доволі багато навчальних закладів не розуміють змісту самого процесу сертифікації, помилково ототожнюючи iï 3 атестацією та іншими процедурами підтвердження відповідності. Сертифікація викладачів - це процедура встановлення відповідності якісних їх характеристик до вимог вітчизняних та / або міжнародних стандартів, призначена оцінити рівень професіоналізму фахівця відповідно до зовнішніх професійних стандартів, тобто розроблених поза конкретною установою.

Питаннями впровадження сертифікації викладачів ВНЗ в Україні почали замислюватися нещодавно. Дистанційна освіта не стала винятком. В зв'язку зі стрімким зростанням інтересу до дистанційного навчання, шукаються шляхи його покращення $\mathrm{i}$ одним 3 аспектів надання високого рівня освітніх послуг $€$ підвищення компетентності професорськовикладацького складу в сфері інформаційних освітніх послуг.

Покращенню професійної компетентності викладачів притаманно безліч причин, але на нашу думку, слід починати вивчення даного питання 3 встановлення та розробки критеріїв для об'єктивної оцінки їх знань та навиків в сфері освіти.

Аналіз останніх досліджень та публікацій. Проблемам забезпечення якості дистанційного навчання присвячені дослідження А. Андреєва, Є. Володимирської, I. Делик, В. Птахіної, І. Ібрагімова, Е. Іванченко, В. Кравця, Г. Ус, Я. Манькута, О. В. Карпаева, О. Васюк, В. Овсяннікова, Н. Хатькова, Ю. Павличенко, В. Олійника, Г. Андріанова та інших.

В роботах С. Федотової, І. Проскуровської, М. Іващенка, Л. Кайдалової, 3. Мнушко, М. Стрюкова, А. Анисимова [1], Р.Г. Мельниченко, Вільяма Хассона, Г. Мурасова [2], 3. Курлянд [3], Кадирової Е. [4], Нікулічевої Н. В. [5] було розглянуто роль викладача (т'ютора) в впровадженні дистанційної освіти та покращення його рівня 
якості. Вирішення деяких питань щодо змішаного навчання та специфіки викладання в даній системі зустрічаємо в публікаціях Орлової М. С., Воджики Е., В. Е. Жужжалова [6], К. А Лісецького [7] тощо.

Питанням формування системи сертифікації персоналу займалися такі дослідники, як Дж. Хейл, Дж. Маккілліп, М. Лінглік-Холл, А. М. Яшин, Г. В. Ніколаєва, Н. Д. Машукова, Н. Ю. Посталюк, М. Є. Курочкін, М. Я. Мухаровський, О. I. Глухова. Вони розглядали цілі i завдання сертифікації персоналу, визначили основні відмінності сертифікації від атестації персоналу та інших форм підтвердження відповідності. Важливо відзначити, що науковці розглядають сертифікацію персоналу не тільки як інструмент, що здатний виконувати внутрішньофірмові завдання, а й як засіб досягнення регіональних i загальнодержавних економічних, соціальних, політичних і духовних цілей.

Однак в роботах цих та інших авторів не приділяється необхідна увага компетентності професорсько-викладацького складу при впровадженні дистанційної освіти, критеріям оцінки навиків та знань їхньої роботи, та в подальшому, сертифікації викладачів в ДО.

Метою роботи $\epsilon$ аналіз вимог до професорсько-викладацького складу (ПВС) 3 урахуванням специфіки дистанційної освіти (ДО), визначення їх критеріїв оцінки компетентності, знань та навиків в ДО, та за допомогою експертної оцінки встановлення найбільш важливих для дистанційного та змішаного навчання.

Викладення основного матеріалу. Проблема оцінки компетентності ПВС в формах освіти 3 широким використанням IКТ потребує детального опрацювання i починати слід 3 вивчення та аналізу більш традиційних форм навчання. В силу специфічних особливостей національної галузі освіти викладач в Україні не має можливості виступати тільки викладачем дистанційної форми навчання. Зазвичай він підпорядкований безпосередньо кафедрі, факультету та університету в якому веде свою діяльність. Цей факт зобов'язує враховувати не тільки критерії компетентності викладача в ДО, а й критерії, необхідні для оцінювання середовища в якому він працює, а саме критерії оцінки навиків та знань викладача в класичній освіті.

Ще однією причиною врахування класичної форми навчання виступає обмежена можливість впровадження дистанційної освіти для інженерних спеціальностей. На наш погляд, у випадку інженерів та медиків лабораторнопрактичні заняття повинні проводитись переважно очно. Аудиторні лабораторні роботи являються необхідним аспектом отримання якісної інженерної освіти. Майбутній інженер, для розвитку всього комплексу виробничих компетентностей, повинен володіти не тільки певним обсягом знань за фахом, а й мати сформовані професійні вміння та навички. У сучасних умовах це неможливо забезпечити без безпосередньої взаємодії 3 промисловим або лабораторним обладнанням, вимірювальними інструментами, матеріалами тощо. Тому i на викладача покладається відповідальність навчити студентів правильно використовувати свої знання та навички на практиці при роботі 3 технікою, що суттєво відрізняє підхід проведення дистанційних практичних робіт. Забезпечити таке навчання за спеціальностями інженерного профілю можливо лише в умовах змішаного навчання, при педагогічно вивіреному 3'єднанні традиційних форм навчання 3 дистанційними технологіями.

В класичній формі освіти для визначення якості викладачів залучають рейтингову оцінку якості ПВС якій притаманне використання показників якості викладачів. Найбільш розповсюдженою та адаптованою рейтинговою оцінкою до кожного університету являється оцінка ПВС МОН України. Оцінка навиків та знань викладачів в багатьох випадках сприймається як рівневий результуючий показник якості наукової, навчально-методичної, виховної діяльності викладача та його статусу (рис. 1), що дозволяє судити про клас, місце, категорію, належність до певної категорії професійно-педагогічної спільноти.

Роль і характер роботи викладача в умовах інформаційного суспільства змінюється, що в свою чергу змушує по-новому поглянути на проблеми розвитку, модернізації системи професійних знань викладацького складу.

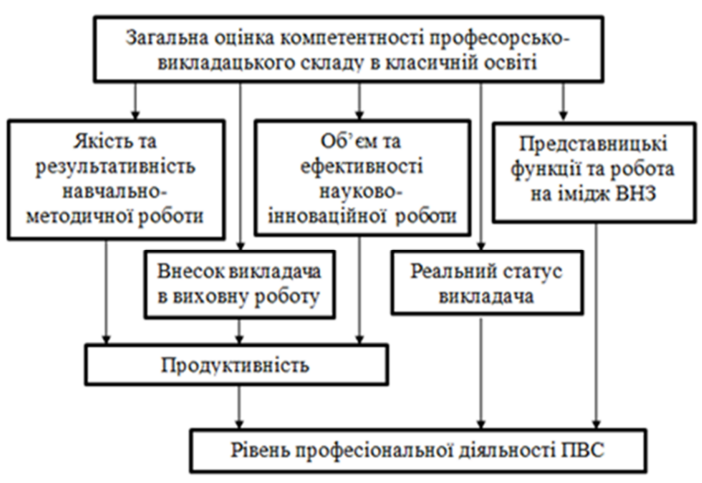

Рисунок 1 - Оцінка якості професорськовикладацького складу (ПВС) в класичній освіті.

На відміну від класичної освіти, у відкритій освіті роль і завдання викладача змінюються. 
Одеська державна академія технічного регулювання та якості

Для впровадження дистанційної освіти залучаються спеціалісти які займаються розробкою, впровадженням, організацією, супроводженням, розміщенням даного матеріалу в відкритому доступі. Викладач (т’ютор) в свою чергу виконує функції координування пізнавального процесу, коректування курсу, консультування при складанні індивідуального навчального плану, керівництво навчальними проектами тощо. Також до обов'язків викладача входять допомога студентам в їх професійному самовизначенні, керування навчальними групами взаємної підтримки.

Визначення рівня компетентності викладачів дистанційної та змішаної форми освіти в першу чергу треба починати зі встановлення критеріїв оцінки набутих викладачем навиків та знань в даних сферах роботи. На основі аналізу публікацій в навчальній та методичній літературі, рейтингах, що мають рекомендації щодо визначення рівня компетентності викладачів ВНЗ України нами був встановлений склад критеріїв компетентності викладачів в системах освіти 3 широким використанням IКT. За основу створюваної системи оцінки компетентності викладача було взято основні критерії ПВС МОН України, що використовуються в класичній освіті, також був проведений аналіз критеріїв оцінки компетентності викладачів в національних i міжнародних університетах, що стрімко впроваджують дистанційну та змішану форми освіти.

В результаті, всю сукупність відібраних критеріїв оцінки ПВС було розбито на шість груп, що відрізняються своєю спрямованістю та роллю в визначенні компетентності ПВС в змішаному навчанні (3Н):

1. Критерії «ПФ»- виконання викладачем представницьких функцій та його робота на імідж ВНЗ.

2. Критерії «НМР» - якість та результативність навчально-методичної роботи ПВС.

3. Критерії «НІР» - опис об’єму та ефективності науково-інноваційної роботи ПВС

4. Критерії «ВР» - внесок викладача в виховну роботу ВНЗ.

5. Критерії «С» - реальний статус викладача ВНЗ.

6. Критерії «ЗН» - приналежність викладача до змішаного навчання.

Критерії перших п’яти груп відповідають загальним вимогам до ПВС ВНЗ в Україні та за кордоном. Остання група вказує на роль ПВС безпосередньо в смішному навчанні, висвітлює специфіку викладання та підходів щодо навчання студентів різних спеціальностей в цілому, та інженерних при залученні змішаної системи освіти.

До складу критеріїв щодо змішаного навчання були включені найбільш часто згадувані в науковій літературі критерії оцінки ПВС для класичної та дистанційної форм навчання. Вони повністю охоплюють сферу діяльності викладача, його статус, викладацьку, організаційну, наукову та нормативно-методичну діяльність, а також діяльність в дистанційній сфері навчання.

Всього в шести запропонованих групах було виділено 192 критерії оцінювання сформованості компетентності викладача, 55 3 них в сфері дистанційного та змішаного навчання (3Н).

На даному етапі дослідження саме шоста група критеріїв буде підлягати розгляду та вивченню. Перші п’ять груп, на відміну від шостої, знайшли широке висвітлення в науковопедагогічній літературі $[1,4,6$ та ін.] і в основному вказують на критерії викладачів ВН3 класичної форми освіти.

Звісно, така кількість критеріїв ускладнює ефективність проведення експертної оцінки, тому їх було розбито на три підгрупи, що більш конкретно розмежовують ролі викладача в змішаному навчанні. Кожна підгрупа відповідає вимогам до рівня компетентності ПВС в даному виді освіти та конкретизує цілі, задачі, які постають перед викладачами під час створення, організації, координування та супроводження курсів:

- розроблення дистанційних курсів;

- супроводження дистанційного курсу;

- розроблення та супроводження курсів в змішаній формі освіти (для інженерних спеціальностей).

По кожній 3 виділених підгруп було проведено анкетування. Метою анкетування $\epsilon$ визначення експертами на їх думку найбільш суттєвих критеріїв компетентності викладача, необхідних для проведення сертифікації ПВС в змішаної освіти.

Першу анкету подавали на розгляд розробникам дистанційних курсів. Експертами в даному дослідженні виступили робітники відділу дистанційної освіти та викладачі, які розроблюють власні курси.

До другої групи експертів увійшли т'ютори та викладачі, які супроводжують дистанційні курси.

Третю групу експертів склали викладачі, які супроводжують професійно-спрямовані дисципліни на очному відділенні, мають досвід використання інформаційно-телекомунікаційних технологій, та в подальшому будуть 
супроводжувати курси для інженерних

спеціальностей в змішаній формі освіти.

Кількісний склад експертних груп визначався відповідно до відомої залежності [8]:

$$
m \geq \sigma^{2} / \mu^{2}+1,
$$

де $m$ - кількість експертів в групі;

$\mu^{2} \quad-$ дисперсія можливих значень вибіркової середньої експертних оцінок;

$\sigma^{2}$ - генеральна дисперсія експертних

Для практичних цілей найбільш прийнятне співвідношення $0,05 \leq \mu^{2} / \sigma^{2} \leq 0,10$ [8]. Так як в використовуваній методиці відсутнє суворе обгрунтування для використання в умовах проведеного експериментального дослідження граничних значень рекомендованого інтервалу змін $\mu^{2} / \sigma^{2}$, тому приймаємо значення $\mu^{2} / \sigma^{2}=0,075$, що відповідає центру інтервалу. Для цього значення, відповідно до залежності (1), кількість експертів $m=15$. Якісний склад експертної групи формувався 3 урахуванням рекомендацій щодо властивостей эксперту [8].

Завданням кожного експерта було провести ранжування та встановити необхідність включення в оцінку сформованості компетентності ПВС для ЗН тих чи інших критеріїв.

Експертна оцінка щодо важливості кожного критерію при визначенні рівня компетентності ПВС в ЗН проводилася 3 використанням непараметричного критерію Фрідмана [9], що найбільш чітко описує даний процес.

В зв'язку 3 алгоритмом застосування критерію Фрідмана на першому етапі аналізу були сформовані дві гіпотези:

1. Гіпотеза Н0: в відібраній групі критеріїв компетентності викладача в ЗН не має значних відмінностей в важливості використання. Всі ці критерії однаково важливі та повинні бути включені в розроблену анкету.

2. Гіпотеза Н1: в групі експертів виявлені значні відмінності в сприйманні важливості окремих критеріїв анкети. Тому недоцільно використовувати критерії, що оцінюються, для розробки загального списку критеріїв оцінки компетентності викладача в ЗН.

Для перевірки висунутих гіпотез всі визначені критерії ранжувались в відповідності 3 їх загальною оцінкою, що розраховувалася підсумовуванням оцінок експертів, проставлених в інтервалі від 0 - «найменш бажаний критерій» до 10 - «найважливіший критерій». В випадку, якщо враховувались не всі критерії, то перед визначенням загальної оцінки усі експертні оцінки попередньо перераховувались, виходячи 3 умови, що оцінка найменш важливого критерію наприкінці повинна бути чисельно рівна кількості критеріїв, що аналізуються.

Для кожного 3 критеріїв розраховувався ранг $R_{i}$ (сума оцінок експертів, які визначали важливість даного критерію для проведення сертифікації ПВС). На основі розрахованого значення виконувалося ранжування критеріїв в порядку спадання рангу та проводилося групування в підмножини $D_{i}$ :

$$
\begin{aligned}
D_{1} & =\left(K_{1}, K_{2}\right), \\
D_{2} & =\left(K_{1}, K_{2}, K_{3}\right), \\
& \ldots \ldots . \\
D_{n-1} & =\left(K_{1}, K_{2}, K_{3} \ldots K_{n}\right),
\end{aligned}
$$

де $K_{i}-$ номер критерію після упорядкування підмножини;

$n$ - номер критерію 3 найменшим рангом в упорядкованій підмножині $D_{n-1}$.

Після встановлювалися емпіричні значення критерію Фрідмана $\chi^{2} \quad 3$ використанням формули:

$$
\chi^{2}=\frac{12}{m \times n \times(n+1)} \times \sum R_{i}^{2}-3 \times m \times(n+1),
$$

де $n$ - кількість критеріїв оцінки знань та навиків ПВС в 3Н;

$R_{i}$ - загальний ранг кожного з критеріїв.

Проміжні результати розрахунку критерію $\chi^{2}$ та відповідні їм рівні значимості р, отримані при аналізі даних щодо критеріїв підгрупи «Розроблення дистанційних курсів» представлені в табл..1. Обчислення проводилися за допомогою програми IBM SPSS Statistics [10].

3 результатів проведеного аналізу (табл.. 1) видно, що при оцінюванні 31 по 11 критеріїв рівень статистичної значущості для $\chi^{2}$ знаходиться в зоні статистичної незначущості $(p>0,05)$ (рис. 2), тобто для даних критеріїв необхідно приймати гіпотезу Н0, що вказує на відсутність відмінностей в оцінюванні важливості критеріїв. 3 результатів випливає, що дані критерії, на думку експертів, однаково необхідні та важливі при встановленні рівня компетентності ПВС для змішаного навчання.

З 12 по 16 критерії оцінки рівня навиків та знань викладачів ЗН існує ймовірність прийняття хибного рішення, тому що рівень статистичної значущості для $\chi^{2}$ знаходиться в зоні невизначеності $(0,05>p>0,01)$. Щодо 17 критерію, то рівень статистичної значущості для $\chi^{2}$ знаходиться в зоні статистичної значущості 
Одеська державна академія технічного регулювання та якості

$(p<0,01)$. Тому необхідно прийняти щодо необхідності включення даного критерію альтернативну гіпотезу $H 1$, що вказує на до системи оцінки компетентності ПВС в ЗН. відсутність єдиної думки в оцінках експертів

Таблиця 1 - Результати обчислення критерію $\chi^{2}$ та рівня значущості за анкетою «Розроблення дистанційних курсів»

\begin{tabular}{|c|c|c|c|c|c|c|c|c|}
\hline$D_{i}$ & $1 \ldots 2$ & $1 \ldots 3$ & $1 \ldots 4$ & $1 \ldots 5$ & $1 \ldots 6$ & $1 \ldots 7$ & $1 \ldots 8$ & $1 \ldots 9$ \\
\hline$\chi^{2}$ & 0,333 & 0,737 & 5,000 & 7,298 & 8,326 & 9,114 & 11,906 & 13,362 \\
\hline$P$ & 0,564 & 0,692 & 0,172 & 0,121 & 0,139 & 0,167 & 0,104 & 0,100 \\
\hline$D_{i}$ & $1 \ldots 10$ & $1 \ldots 11$ & $1 \ldots 12$ & $1 \ldots 13$ & $1 \ldots 14$ & $1 \ldots 15$ & $1 \ldots 16$ & $1 \ldots 17$ \\
\hline$\chi^{2}$ & 14,846 & 17,128 & 21,911 & 23,955 & 26,904 & 28,933 & 30,417 & 35,688 \\
\hline$P$ & 0,095 & 0,072 & 0,025 & 0,021 & 0,013 & 0,011 & 0,011 & 0,003 \\
\hline
\end{tabular}

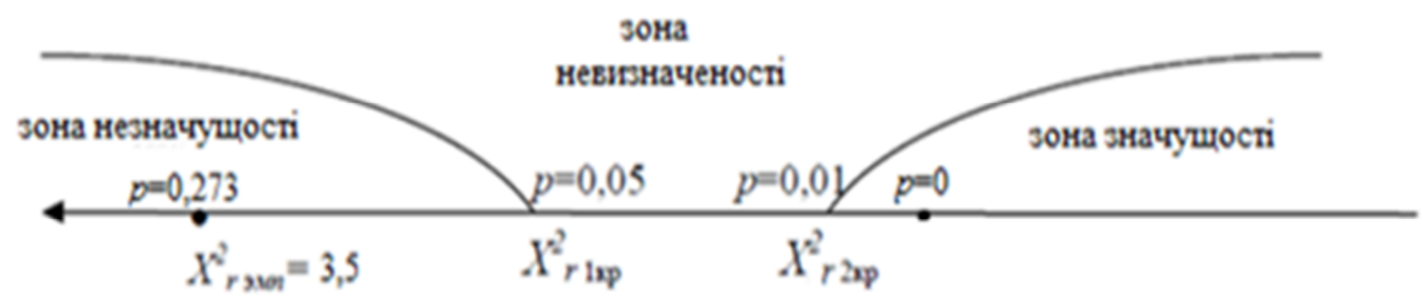

Рисунок 2 - Рівень статистичної значущості для $\chi^{2}$

Аналогічним чином проводилось обчислення за результатами двох інших анкет «Супроводження дистанційного курсу» та «Розроблення та супроводження курсів в змішаній формі освіти (для інженерних спеціальностей)».

Результати дослідження. Оброблення результатів експертного аналізу за всіма підгрупами дозволили створити узагальнений список критеріїв, що являються необхідними для проведення сертифікації викладачів при змішаному навчанні студентів інженерних спеціальностей.

Розроблення дистанційних курсів:

1. Компетенції в розробленні віртуальних тренажерів, симуляторів.

2. Досвід розроблення повного дистанційного курсу.

3. Компетенції в розробленні сценаріїв дисциплін дистанційного курсу.

4. Досвід в використанні технологій проектування мультимедійних та інтерактивних цифрових освітніх ресурсів (флеш-технологій, $3 \mathrm{~d}$ max тощо).

5. Компетенції в розробленні текстовографічних цифрових освітніх ресурсів для дистанційного навчання.

6. Досвід розроблення цифрових освітніх ресурсів для очного та змішаного навчання.

7. забезпечення дистанційної освіти i авторського права.

8. Компетенції в розробленні відео семінарів.

9. Компетенції в створенні дистанційного курсу у якості експерта.

10. Досвід розміщення навчальнометодичних матеріалів дисциплін у відкритому доступі.

11. Володіння мовами програмування (perl, java, php тощо).

Супроводження дистанційного курсу:

1. Компетенції в організації та стимулюванні самостійної пізнавальної діяльності студентів.

2. Компетенції в організації та стимулювання зворотного зв'язку.

3. Досвід розроблення та проведення тестування.

4. Досвід організації та проведення електронного навчання в локальній мережі та через Інтернет.

5. Проходження курсів підвищення кваліфікації щодо специфіки викладання ДО.

6. Досвід участі в роботах міжнародних та національних наукових спільнотах щодо удосконалення ДО. 
7. Досвід створення індивідуальних та групових он-лайн проектів.

8. Компетенції щодо контролю динаміки результатів знань студентів.

9. Компетенції в організації співпраці студентів між собою в віртуальному середовищі.

10.Досвід консультування щодо використання дистанційних методів навчання.

11.Компетенції в координуванні навчальною діяльністю віртуальної групи студентів.

12.Досвід участі у заходах з оприлюдненням електронних навчальних матеріалів.

13.Знання психологічних особливостей спілкування у віртуальному середовищі.

14.Досвід проведення он-лайн вебінарів, чат-конференцій, форумів, блогів.

15.Стажування в відділі супроводу ДО в якості т'ютора.

Розроблення та супроводження курсів в змішаній формі освіти (для інженерних спеціальностей):

1. Проходження курсів підвищення кваліфікації в області змішаного навчання.

2. Досвід розробки та проведення практичних і лабораторних робіт.

3. Досвід проведення практичних занять, дослідницьких i експериментальних робіт на натурних моделях та промислових зразках.

4. Компетенції проведення практичних занять, досвідчених і експериментальних робіт на електронних моделях.

5. Компетенції володіння програмними засобами автоматизації технічної підготовки виробництва (Компас3D, AutoCAD, SolidWorks, MathCAD і т.п.).

6. Досвід розробки повного курсу або повного циклу лабораторно-практичних робіт для змішаної системи навчання.

7. Компетенції використання засобів інформаційно-технічної підтримки (засоби проекційного зображення, електронна пошта, пристрої сканування, друку і т.п.).

8. Практичний досвід роботи в галузі.

9. Досвід організації групових індивідуальних проектів (онлайн або аудиторних).

10.Досвід розробки методичних рекомендацій i навчальних посібників для проведення практичних і лабораторних занять в умовах змішаного навчання.

11.Досвід проектування змісту навчальних матеріалів, що відповідає сучасним досягненням галузевої науки і практики.

12.Компетенції в області проведення групових та індивідуальних консультацій 3 використанням Інтернет-ресурсів.
13.Компетенції пошуку, обробки, передачі та подання конструкторсько-технологічної інформації 3 використанням корпоративних i глобальних комп'ютерних мереж.

14.Знання основного змісту і структурнологічних зав'язків навчальних курсів, модулів, практик, що входять в освітню програму спеціальності.

15.Компетенції використання засобів комп'ютерного контролю для перевірки сформованості професійних умінь i навичок роботи студентів.

16.Компетенції в області орієнтації студентів на використання досліджуваного матеріалу в майбутній професійній діяльності.

17.Досвід розроблення графічноорієнтованих цифрових освітніх ресурсів для інженерних спеціальностей.

18.Досвід розробки навчальних робочих програм змішаного навчання для конкретної навчальної дисципліни.

19.Досвід участі у формуванні банку засобів об'єктивного контролю для проведення державного іспиту за спеціальністю.

20.Досвід керівництва науковою роботою магістра, дипломними і курсовими проектами.

21.Досвід участі в розробці компетентнісної моделі випускника, паспортів та освітньокваліфікаційних характеристик.

\section{Висновки}

Внесення змін до описаної системи оцінки компетентності ПВС в ЗН дозволяє розробити нові підходи щодо впровадження сертифікації викладачів під час розробки, організації та супроводження курсів в змішаному навчанні. В загальному підсумку, на основі рішень експертів, нами було встановлено 47 критеріїв компетентності викладачів змішаної форми освіти для інженерних спеціальностей. Перспективним для подальших досліджень $\epsilon$ використання розробленої системи критеріїв оцінки навиків та знань ПВС для підвищення рівня компетентності викладачів та освітніх послуг при впровадженні змішаної форми освіти в навчальний процес.

Ціллю подальших досліджень є більш глибше розкриття питання сертифікації ПВС та детальніший розгляд особливостей використання встановлених критеріїв для підвищення рівня компетентності ПВС під час викладання дисциплін інженерного профілю в умовах змішаної освіти.

\section{Список використаних джерел}

1. Анисимов А. П. Рейтинг преподавателей, как основной показатель при аккредитации вуза / 
Одеська державна академія технічного регулювання та якості

А. П. Анисимов, Р. Г. Мельниченко // Право и образование - № 6 - 2011. - Режим доступа: http://melnichenko.net/_p_name159.html.

2. Мурасова Г. Є. Специфіка роботи викладача в системі дистанційної освіти / Г. С. Мурасова // Матеріали IV Міжнар. наук.практ. конф. «Освітній процес: погляд зсередини», 29-30 листоп. 2010 р.: [Електронний ресурс].

Режим доступу: http://www.confcontact.com/20102911/4_muras.htm

3 Курлянд 3. Н. Теорія i методика професійної освіти : навч. посіб. / 3. Н. Курлянд, Т. Ю. Осипова, Р. С. Гурін, І. О. Бартєнєва, I. М. Богданова; ред.: 3. Н. Курлянд. - К.: Знання, 2012. - 390 с. - Бібліогр.: 324 назв - укр.

4. Кадырова Э. А. Реализация компетентностного подхода при подготовке преподавателя для СДО вуза / Э. А. Кадырова // Перша всеукраїнська науково-практична конференція MoodleMoot Ukraine 2013. Теорія i практика використання системи управління навчанням Moodle - Київ, 2013 [Електронний ресурс]. http://2013.moodlemoot.in.ua/course/view.php?id=7 5 \&lang $=\mathrm{ru}$.

5. Никуличева Н. В. Какими компетенциями должен обладать преподаватель дистанционного обучения и как их сформировать / Н. В. Никуличева // e-Learning PRO. - № 11. 2009. - Режим доступа: http://www.elearningpro.ru/page/zhurnal-pro-

elearning.

6. Жужжалов В. Е. Современные требования к подготовке инженерных кадров / В. Е. Жужжалов, О.А.Баранова // Молодой ученый. - 2014. - № 2. - С. 757-759.

7. Лісецький К. А. Змішані і традиційні форми навчання / К. А. Лісецький // Сучасні методи викладання іноземної мови професійного спрямування у вищій школі: Збірник наукових статей - К.: НТУУ «КПІ», 2013. - 442 с. - С. 223235.

8. Постников В. М. Анализ подходов к формированию состава экспертной группы, ориентированной на подготовку и принятие решений / В. М. Постников // Наука и образование. - М., 2012. - №5 - С. 333 - 346.

9. Шелехова Л. В. Математические методы в педагогике и психологии: в схемах и таблицах / Л. В. Шелехова - Майкоп, изд-во АГУ, 2010. 192 с. 10. IBM SPSS Statistics. - Режим доступу: http://www.predictivesolutions.ru/software/statistics. $\mathrm{htm}$ - Загл. с экрана.

Надійшла до редакиії 12.05.2016

Рецензент: д.т.н., професор Залога В. О., Сумський державний університет, м. Суми

Е. А. Лозовая, А. Н. Алексеев, д.пед.н.

\section{СЕРТИФИКАЦИЯ ПРОФЕССОРСКО-ПРЕПОДАВАТЕЛЬСЬКОГО СОСТАВА ПРИ СМЕШАННОМ ОБРАЗОВАНИИ}

В статье рассматриваются вопросы сертификаиии профессорско-преподавательского состава вузов при внедрении смешанной формы образования. Проанализированы и сгруппированы критерии компетентности преподавателя в системе образования с широким использованием ИКТ. Особое внимание уделено экспертной оценке представленных критериев и выявлению наиболее значимых из них для инженерных специальностей. На основе исследования доработана система оценки $u$ предложены новые критерии компетентности преподавателя смешанной формы образования.

Ключевые слова: профессорско-преподавательский состав (ПВС), смеманная форма образования, сертификация преподавателей, профессиональные компетенции, критерии компетентности преподавателей, экспертная оченка.

K. A. Lozova, O. M. Alekseev, $\mathrm{PhD}$

\section{CERTIFICATION OF THE TEACHING STAFF IN BLENDED FORM OF EDUCATION}

The article deals with the certification of the faculty staff of the universities in the implementation of blended education. The criteria of teacher's competence in education with extensive use of ICT were analyzed and grouped. Special attention was paid to expert assessment of the represented criteria definition of the most important among them for engineering specialties. On the basis of the research the system of assessment was improved and new criteria of teacher competencies of blended learning were proposed.

Keywords: teaching staff (TS), blended form of education, certification of teachers, professional competence, evaluation competency of teachers, peer review. 